\title{
Determination of progesterone compounds in the crude methanol extract of benalu duku leaves
}

\author{
Lazuardi Mochamad ${ }^{1}$, Bambang Hermanto ${ }^{2}$ and E. P. Hestianah ${ }^{3}$
}

1. Laboratory Veterinary Pharmacy, Faculty of Veterinary Medicine, Universitas Airlangga, Mulyorejo Rd., "C" Campus Surabaya, Surabaya 60115, Indonesia; 2. Department of Pharmacology, Faculty of Medical, Universitas Airlangga, Mayjen. Prof. Dr. Moestopo 47 Rd., "A" Campus Surabaya, Surabaya 60132, Indonesia; 3. Laboratory Histology, Faculty of Veterinary Medicine, Universitas Airlangga, Mulyorejo Rd., "C" Campus Surabaya, Surabaya - 60115, Indonesia.

Corresponding author: Lazuardi Mochamad, e-mail: lazuardi@fkh.unair.ac.id

Co-author: BH: bambanghermanto506@gmail.com,EPH: ekamirta@gmail.com

Received: 29-10-2018, Accepted: 25-01-2019, Published online: 04-03-2019

doi: 10.14202/vetworld.2019.358-366 How to citethis article: MochamadL, Hermanto B, Hestianah EP(2019)Determination of progesterone compounds in the crude methanol extract of benalu duku leaves, Veterinary World, 12(3): 358-366.

\begin{abstract}
Background and Aim: Dendrophthoe pentandra L. Miq (benalu duku) is a parasitic herb that commonly grows on the host plant Lansium domesticum. Researchers have found that the plant contains anticancer compounds and may contain phytoandrogens, including progesterone-like compounds, in its crude methanol extract. The objective of the current study was to investigate the compound of phyto progesterone in benalu duku leaves after extracted by methanol and prepared using an analytical column of high-performance liquid chromatography (HPLC).
\end{abstract}

Materials and Methods: About $400 \mathrm{~g}$ of benalu duku leaves were pulverized, and their compounds were isolated by the isocratic method using an RP-18 analytical column $(5 \mu \mathrm{m})$ with a mobile phase of 70:30 (methanol: water) in a photodiode array detector adjusted to $254 \mathrm{~nm}$. The phyto progesterone compound was identified at a retention time of approximately $6.01 \mathrm{~min}$.

Results: By LC-electrospray ionization mass spectrometry focusing on molecular fractions, the fingerprint area of the Fourier transform-infrared spectroscopy (FT-IR, $\mathrm{cm}^{-1}$ ) and ${ }^{\mathrm{H}}$ nuclear magnetic resonance (NMR) spectra indicated that the phyto progesterone product isolated was identical to the certified reference material of pure progesterone, particularly the specific functional groups in the FT-IR spectrum at wavenumbers of $1317.43 \mathrm{~cm}^{-1}$ and $1386.86 \mathrm{~cm}^{-1}$ and in the proton ${ }^{\mathrm{H}} \mathrm{NMR}$ spectrum at carbon 21 of progesterone $(\mathrm{p}<0.05)$.

Conclusion: Each $49.888 \mu \mathrm{g} / \mathrm{mL}$ of crude benalu duku leaf extract dissolved in the mobile phase contained $28.515 \pm 0.713 \mu \mathrm{g} / \mathrm{mL}$ phyto progesterone.

Keywords: Androgenic phyto progesterone, ${ }^{\mathrm{H}}$ nuclear magnetic resonance of crude methanol extract, Isolation technique of progesterone, molecular fractions, progesterone compounds in crude methanol extract, progesterone-like effect.

\section{Introduction}

Medicinal plants from around the world have contributed to almost $70 \%$ of therapeutic benefits in humans and animals. Benalu duku, for example, is a medicinal plant used as an alternative to synthetic cancer drugs [1-3]. Benalu duku is commonly known as a parasite of its host, Lansium domesticum [4,5]. The plant is distributed throughout the tropical and subtropical regions of Indonesia, Malaysia, the Philippines, and Thailand [6,7].

Benalu duku leaves are traditionally used to treat breast cancer and various other diseases involving cell proliferation [8-10]. Its crude methanol extract is reported to contain $0.033 \mathrm{mg}$ L-asparagine, $0.017 \mathrm{mg}$ L-threonine, $0.017 \mathrm{mg}$ L-serine, 0.042 $\mathrm{mg}$ L-glutamine, $0.019 \mathrm{mg}$ glycine, $0.018 \mathrm{mg}$

Copyright: Mochamad, et al. Open Access. This article is distributed under the terms of the Creative Commons Attribution 4.0 International License (http://creativecommons.org/licenses/ by/4.0/), which permits unrestricted use, distribution, and reproduction in any medium, provided you give appropriate credit to the original author(s) and the source, provide a link to the Creative Commons license, and indicate if changes were made. The Creative Commons Public Domain Dedication waiver (http:// creativecommons.org/publicdomain/zero/1.0/) applies to the data made available in this article, unless otherwise stated.
L-alanine, $0.013 \mathrm{mg}$ L-cysteine, $0.017 \mathrm{mg}$ L-valine, $0.023 \mathrm{mg}$ L-methionine, $0.018 \mathrm{mg}$ L-isoleucine, $0.028 \mathrm{mg}$ L-leucine, $0.01 \mathrm{mg}$ L-tyrosine, 0.021 mg L-phenylalanine, $0.015 \mathrm{mg}$ L-lysine, 0.008 mg L-histidine, $0.019 \mathrm{mg}$ L-arginine, $0.021 \mathrm{mg}$ L-proline, $0.009 \mathrm{mg}$ L-hydroxyproline, $0.0003 \mathrm{mg}$ L-hydroxylysine, and $0.007 \mathrm{mg}$ ammonia per 4.385 $\mathrm{g}$ of leaves $[4,11]$. Benalu duku leaf infusion is nontoxic, especially in experimental animal models. Other compounds in the methanol extract of benalu duku leaves as detected by infrared spectrophotometry and thin-layer chromatography include hydroxyls, carbonyls, double-link carboxyls, and amine groups, in addition to alkaloids, flavonoid polyphenols, terpenoids, and steroids. In early 2013, researchers stated that crude methanolic extract from benalu duku leaves was predicted to contain plant hormone compounds for fertilization. Later research explained that crude methanolic extract from benalu duku leaves orally administered to female mice increased their progesterone levels $[4,8,9]$. Crude extract from benalu duku leaves obtained using maceration method dissolved in methanol was shown to contain four progesterone hormone derivatives with progesterone-like effects. 
The known active compounds that produce progesterone-like effects are steroid group of pregnane derivatives as prenanes, pregnandiene, and pregnanetriene. The pregnandiene and pregnanetriene are not strongest to stimulate progeterone-like effect. However, the prenanes is good to stimulate androgenic effect as progesterone, medroxyprogesterone acetate, megestrol acetate, and dydrogesterone [4,12].

This research aimed to obtain the active compound, progesterone or pregn-4-ene-3,20-dione $\left(\mathrm{C}_{21} \mathrm{H}_{30} \mathrm{O}_{2}\right)$, after isolation by a modified preparation technique using high-performance liquid chromatography (HPLC) to analyze the compounds. The benefit of this research was that it obtained true compounds from HPLC separation through adsorption and partition from controlled chromatograms of the analyte peaks.

\section{Materials and Methods}

\section{Ethical approval}

This research has been approved by Ethics Commission of Veterinary Medicine, Universitas Airlangga with no. 1 KE 132.07.2018, date 31 July 2018 by Dean of Faculty of Veterinary Medicine, Universitas Airlangga.

\section{Certified reference material (CRM) progesterone and collection of plant material}

The progesterone standard for determining the bioactive progesterone compounds in the crude methanol extract of benalu duku leaves was obtained from Sigma-Aldrich Co., USA Lot No. SZBA321XV, with a molecular weight of 314.46, as shown in Figure-1. Benalu duku leaves were obtained from the Muara Enim district (south of Sumatra) and identified by the Research Center of Biology, Republic of Indonesia, at Raya Jakarta-Bogor Km. 46 Cibinong, West Java 16911, Indonesia. The benalu duku (Dendrophthoe pentandra L. Miq.) had been grown in $L$. domesticum for 5 years.

\section{Instrumental analysis}

Instrumental analysis of the separated bioactive compounds from the matrix samples was conducted by HPLC using a Shimadzu CBM-20A Communication Bus Module to interact with a photodiode array detector in an ultraviolet-visible (UV-visible) M20A spectrometer, in which a LiChrospher ${ }^{\circledR} 100 \mathrm{RP}-18$ column was fitted. The Fourier transform-infrared spectroscopy (FT-IR) instrument used was a Shimadzu IRAFFINITY-1S model at the scanning wavenumbers $500-4000 \mathrm{~cm}^{-1}$. The LC mass spectrometry (LC-MS) instrument was an Acella Triple Quadrupole Quantum Access Thermo with a Hypersil Gold $0.2 \mu \mathrm{M}$ column of $10 \mathrm{~cm}$ in length. The nuclear magnetic resonance (NMR) instrument was a JEOL ECS-400, and analyses were performed using $\mathrm{D}_{2}$-grade methanol. All chemical reagents for HPLC, LC-MS, and sample preparation were of chromatographic and analytical grade.

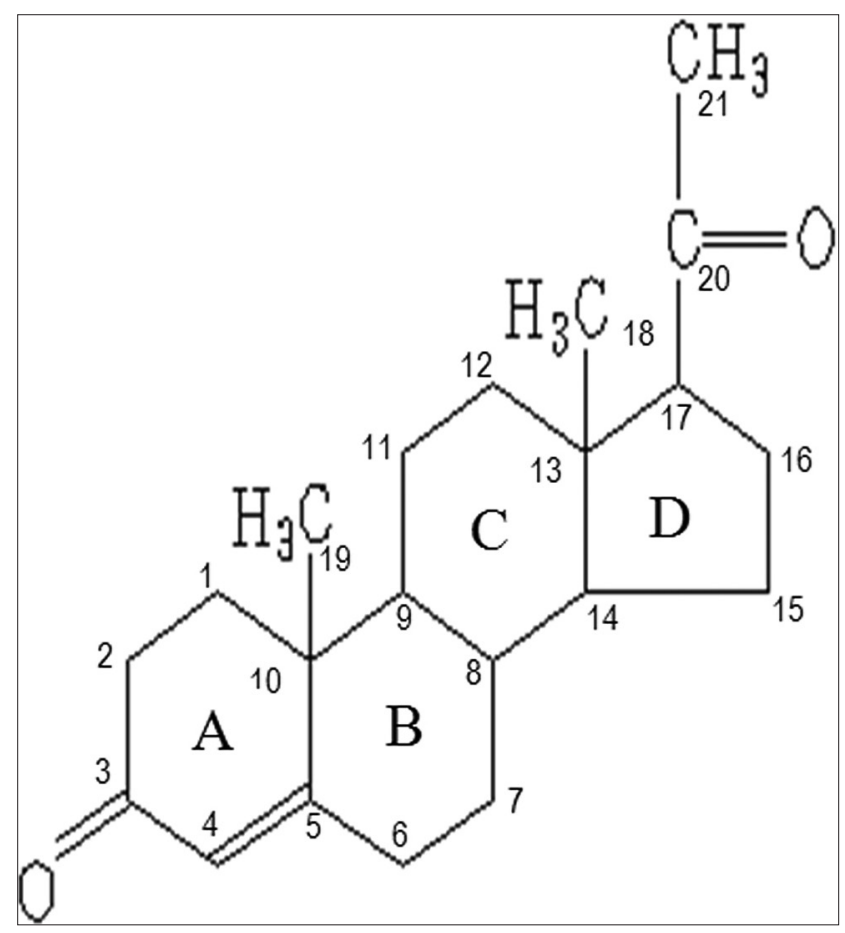

Figure-1: Molecular structure of progesterone or (8S,9S,10R,13S,14S,17S)-17-acetyl-10,13-dimethyl$1,2,6,7,8,9,10,11,12,13,14,15,16,17$-tetradecahydro-3Hcyclopenta[a]phenanthren-3-one.

\section{Preparation of methanolic extract of benalu duku} leaves

The materials were cleaned, weighed to approximately $400 \mathrm{~g}$, and pulverized; then, the powdered plant material was soaked in $1.0 \mathrm{~L}$ of absolute methanol for $24 \mathrm{~h}$ with occasional shaking. The mixture was filtered by a Buchner funnel and centrifuged at $3000 \mathrm{rpm}$ for $15 \mathrm{~min}$. The supernatants were collected in a specialized colored glass bottle and then dried under warm blowing nitrogen vapor $\left(40^{\circ} \mathrm{C}\right)$. The soaking and filtration were repeated twice. The percentage yield of the dried extract was calculated. The extracts were stored in desiccators until further use $[13,14]$.

\section{Research design}

The research design was determined post-test only control groups, as described by Maraghehpour et al. [15] and Morrill et al. [16]. The total samples (n) were calculated as follows:

$$
\mathrm{N}=\frac{\left.\left[\mathrm{Z}_{\mathrm{a}}-\frac{\mathrm{a}}{2}\right]+\mathrm{Z}\right]}{\frac{\mathrm{d}^{2}}{\mathrm{Sa}^{2}+\mathrm{Sb}^{2}}}
$$

The $Z_{1}-\alpha / 2$ at $5 \%$ significance was 1.96 , and the $Z_{\beta}$ at $5 \%$ error was 1.645 . The tolerance of $d$ was 3.62 . The standard deviation of the sample trials (Sa) was 1.7, and the standard deviation of the control was 1.4. Equation 1 yielded an $(\mathrm{N})$ of five research objects [4].

\section{Research protocol}

The research protocol was performed as described below, following the steps listed in each section. Part 1: $400 \mathrm{~g}$ of pulverized benalu duku leaves 
were added to $1 \mathrm{~L}$ of methanol for the $1^{\text {st }}$ percolation and extraction by a moving method over $48 \mathrm{~h}$. The supernatant was then collected in a specialized bottle. The extract was added to $1 \mathrm{~L}$ of methanol for the $2^{\text {nd }}$ percolation; then the $2^{\text {nd }}$ supernatant was collected. All supernatants were dried by a vacuum method, then collected, weighed, and stored in desiccators. The HPLC system was set to isocratic method parameters: Detection at $254 \mathrm{~nm}$, a flow rate of $0.5 \mathrm{~mL}$, stop time at $20 \mathrm{~min}$, a mobile phase solution of $70 \%$ methanol:30\% water, and a loop injection capacity of $40 \mu \mathrm{L}$. Part 2: The CRM for progesterone was dissolved (b/v) in the mobile phase solution at serial concentrations of $0.5,0.75$, and $1 \mu \mathrm{g} / \mathrm{mL}$, then injected into the HPLC system in $0.5 \mu \mathrm{L}$ aliquots. The benalu duku leaf crude extract was dissolved in the mobile phase solution, then filtered using a $0.20 \mu \mathrm{m}$ filter and injected into the HPLC system. The chromatogram of the progesterone CRM versus those of the samples was compared using the retention time (RT) peak, and the progesterone concentrations in the samples were calculated. Part 3: Progesterone compounds in the matrix samples were isolated using the analyte column based on the CRM's RT, and the waste product analyte was collected from the HPLC apparatus.
The isolated product was analyzed using infrared spectra to characterize the progesterone compounds after comparing them to the CRM, particularly at wavenumbers $500-1000 \mathrm{~cm}^{-1}$ and $1100-1750 \mathrm{~cm}^{-1}$. The isolated product was assessed mass spectrum fragmentation (molecular fractions $[\mathrm{m} / \mathrm{z}]$ ) of phyto progesterone and comparing to reference material of progesterone by LC-MS with electrospray ionization (ESI) MS [17]. The Acella parameters were set for autosampling at a capacity of $10 \mu \mathrm{L}$, column cleaning at $100 \mu \mathrm{L} / \mathrm{s}$, and a stop time at 6 min determined by a vial sample capacity of $1.2 \mathrm{~m}$. The column temperature was set at $22^{\circ} \mathrm{C}$, and the pressure control was set at 10 bar. Part 4: The progesterone compounds isolated from the matrix samples were tested by proton NMR and compared with the proton NMR results for the progesterone CRM. Part 5: The data from sample testing versus the CRM was analyzed using MINITAB, version 17.0 at $5 \%$ significance, and the conclusion and recommendations were determined [18].

\section{Results}

The crude extract from $400 \mathrm{~g}$ of pulverized benalu duku leaves yielded $40 \mathrm{~g}$ of matrix samples. The results indicated that RT of the progesterone

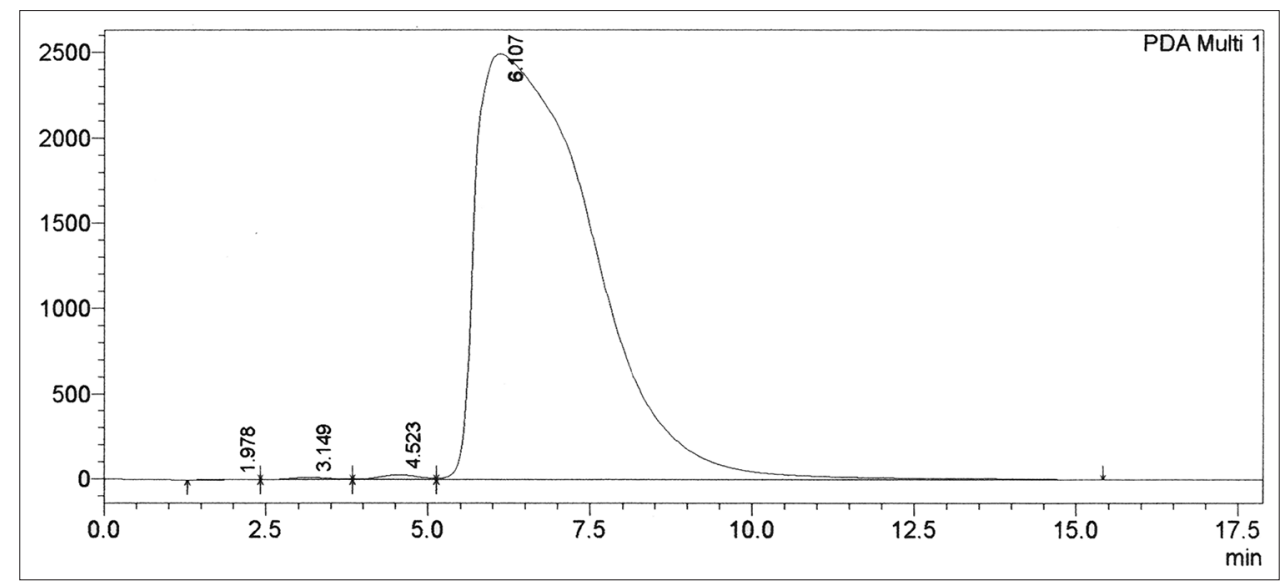

Figure-2: Progesterone certified reference material at $5 \mu \mathrm{g} / \mathrm{mL}$ in the mobile phase solution (methanol $70 \%$ :water $30 \%$ ) at a wavelength of $254 \mathrm{~nm}$, with a retention time of $6.107 \mathrm{~min}$.

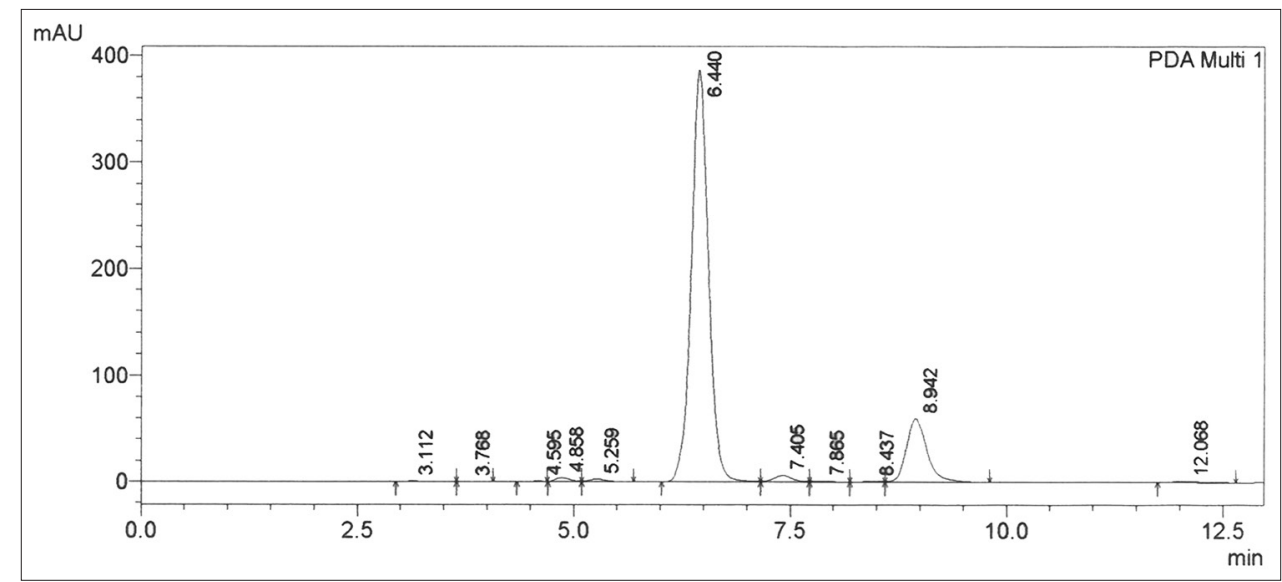

Figure-3: Chromatogram peaks from the crude methanol extract of benalu duku leaves dissolved in the mobile phase (methanol pro-high-performance liquid chromatography $70 \%$ : water pro-high-performance liquid chromatography $30 \%$ ). The phyto progesterone was eluted at the retention time of $6.182 \mathrm{~min}$. 
CRM at $5 \mu \mathrm{g} / \mathrm{mL}$ by HPLC was $6.107 \mathrm{~min}$ (Figure-2).

Figure- 3 shows that the benalu duku leaf crude extract dissolved in the mobile phase solution had three group peaks. The RTs were 4-6.5 min for the first group, 7.30-12.672 min for the second group, and 16.573-20.00 min for the third group.

Figure-4 shows the characterized infrared spectrum of the CRM in blue, while the isolated crude extract isolated from the benalu duku leaves is shown in red, with specific functional group peaks between wavenumbers $464.86 \mathrm{~cm}^{-1}$ and $949.01 \mathrm{~cm}^{-1}$ and $1161.19 \mathrm{~cm}^{-1}$ and $1699.34 \mathrm{~cm}^{-1}$. A non-specific peak presented between $2000 \mathrm{~cm}^{-1}$ and $4000 \mathrm{~cm}^{-1}$. The advantages of the infrared spectrum for CRM versus isolate from the benalu duku leaves are described in data obtained from Table- 1 .
Figure-5 shows that the isolated samples contained compounds similar to progesterone, as determined with reference to the CRM RT of $4.17 \mathrm{~min}$ with a $294.50-295.50 \mathrm{~m} / \mathrm{z}$ ratios. Comparing the samples to the progesterone CRM in Figure-6 shows that at $296.50-297.50 \mathrm{~m} / \mathrm{z}$ ratios, the ESI of CRM 315.000 was approximated to samples at ESI 313.000. The assessed area under the chromatogram of the benalu duku leaf crude extract of automatic area (AA) 22566 from Figure-5 was used to calculate the progesterone concentration based on the area under the chromatogram of the CRM, which was AA 39914 (Figure-6) at a $50 \mu \mathrm{g} / \mathrm{mL}$ concentration, yielding a $28.268 \mu \mathrm{g} / \mathrm{mL}$ concentration (Table-2, No. 1).

The ${ }^{1} \mathrm{H}-\mathrm{NMR}$ results for the CRM dissolved in

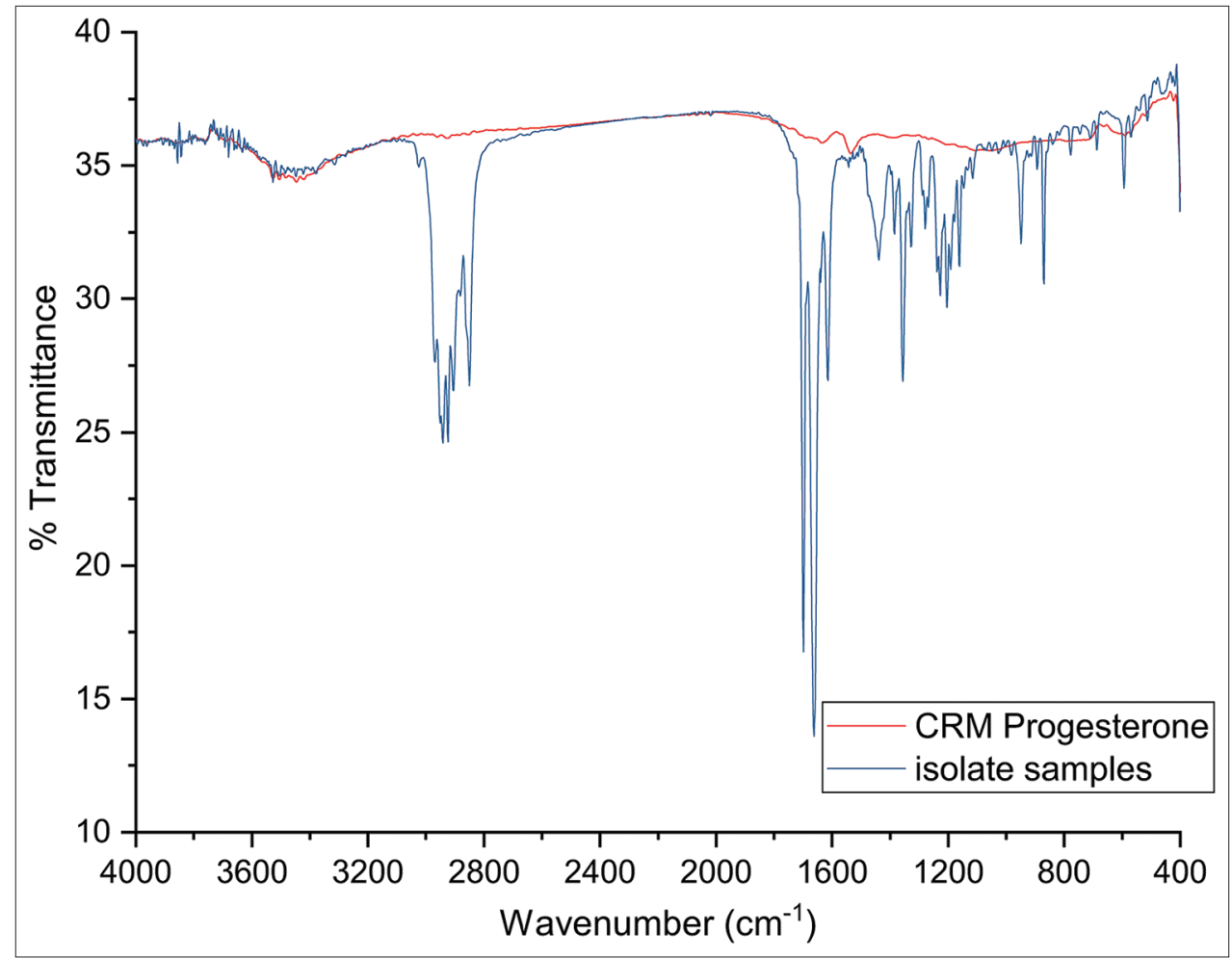

Figure-4: Infrared spectrum of the certified reference material (progesterone) by Fourier transform-infrared in $\mathrm{KBr}$, with specific functional group peaks at wavenumbers $464.86 \mathrm{~cm}^{-1}-949.01 \mathrm{~cm}^{-1}$ and $1161.19 \mathrm{~cm}^{-1}-1699.34 \mathrm{~cm}^{-1}$.

Table-1: Interpretation of the infrared spectrum results for both the CRM and sample analytes.

\begin{tabular}{|c|c|c|c|c|c|}
\hline \multicolumn{3}{|c|}{ CRM of progesterone } & \multicolumn{3}{|c|}{ Isolate from crude methanol extract of benalu duku leaves } \\
\hline Peak $\left(\mathrm{cm}^{-1}\right)$ & Intensity & Compounds & Peak $\left(\mathrm{cm}^{-1}\right)$ & Intensity & Compounds \\
\hline 594.100 & 34.150 & $\mathrm{H} 2 \mathrm{C}=\mathrm{O}$ & 590.24 & 36.115 & $\mathrm{H} 2 \mathrm{C}=\mathrm{O}$ \\
\hline 1329.00 & 31.951 & Single aromatic & 1317.43 & 36.117 & Single aromatic \\
\hline 1356.00 & 26.907 & Single aromatic & 1386.86 & 36.042 & Single aromatic \\
\hline 1384.94 & 32.441 & Ring of naphthalene $(t)$ & None & None & None \\
\hline 1438.94 & 31.457 & Ring of naphthalene $(t)$ & 1537.22 & 35.450 & Ring of naphthalene ( $t$ ) \\
\hline 1614.47 & 26.935 & Ring of anthracene (s) & 1633.76 & 35.849 & Ring of anthracene (s) \\
\hline 1662.69 & 13.601 & Ring of anthracene (s) & & & \\
\hline 1699.34 & 13.601 & Ring of anthracene (s) & 1689.70 & 36.045 & Ring of anthracene (s) \\
\hline None & None & None & 2850.88 & 26.748 & $\mathrm{R}-\mathrm{C}-\mathrm{OH}$ \\
\hline None & None & None & 2904.89 & 26.564 & $\mathrm{R}-\mathrm{C}-\mathrm{OH}$ \\
\hline 2926.11 & 36.023 & $\mathrm{R}-\mathrm{C}-\mathrm{OH}$ & 2941.54 & 24.604 & $\mathrm{R}-\mathrm{C}-\mathrm{OH}$ \\
\hline None & None & None & 2968.55 & 27.633 & $\mathrm{R}-\mathrm{C}-\mathrm{OH}$ \\
\hline 3446.91 & 34.383 & $\mathrm{R}-\mathrm{C}-\mathrm{OH}$ & 3485.49 & 34.700 & $\mathrm{R}-\mathrm{C}-\mathrm{OH}$ \\
\hline
\end{tabular}

$\mathrm{t}=$ twist, $\mathrm{s}=$ scissor, $\mathrm{CRM}=$ Certified reference material 


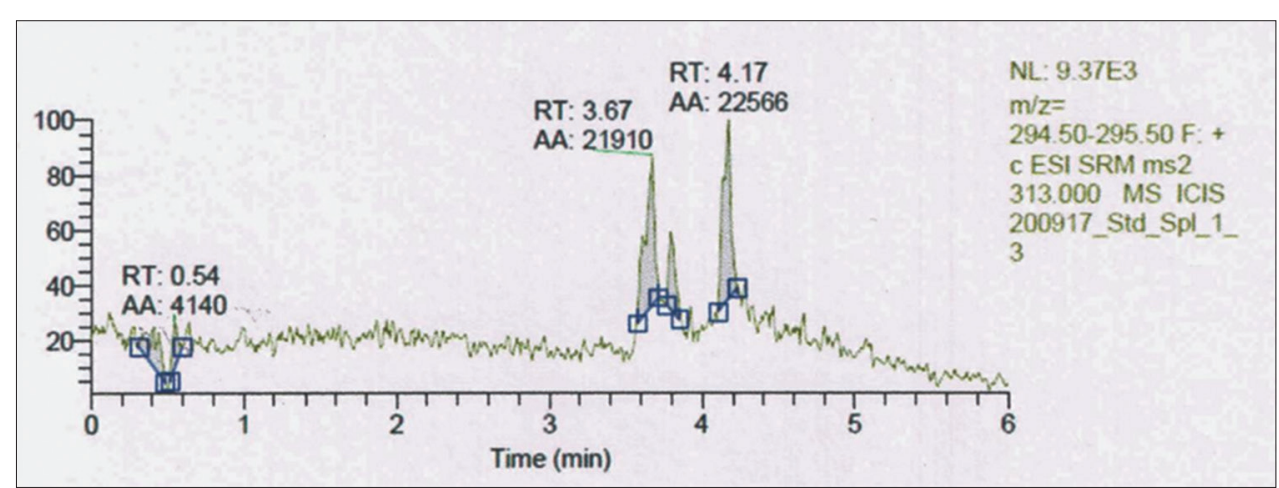

Figure-5: Liquid chromatography-electrospray ionization-mass spectrometry of the benalu duku leaf crude extract at $294.50-295.50 \mathrm{~m} / \mathrm{z}$. The ESI-MS2 313 retention time of $4.17 \mathrm{~min}$ and the chromatogram area of 22566 yielded a progesterone concentration of $28.268 \mu \mathrm{g} / \mathrm{mL}$.

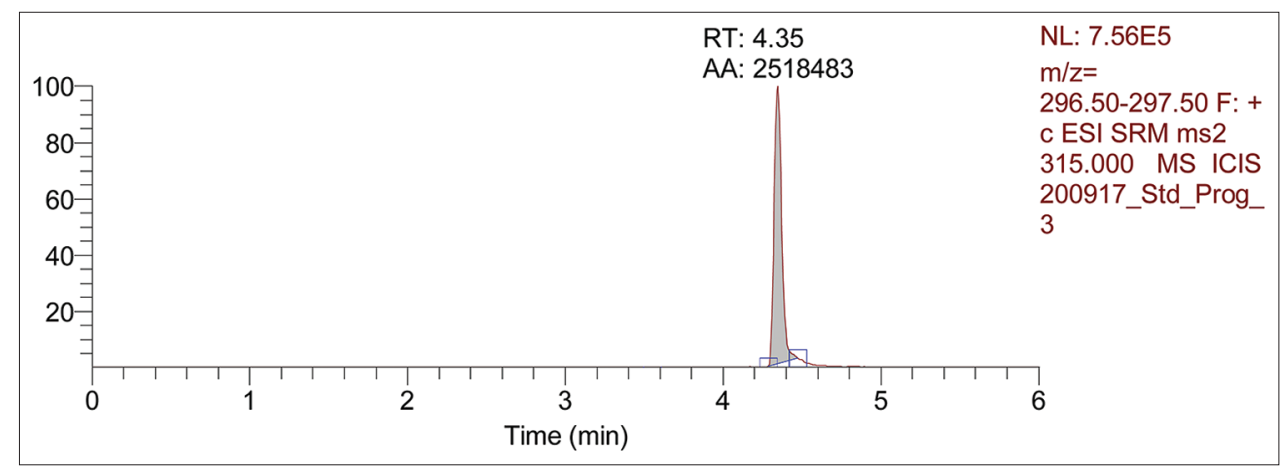

Figure-6: Liquid chromatography-electrospray ionization-mass spectrometry (ESI-MS) of the progesterone certified reference material at $50 \mu \mathrm{g} / \mathrm{mL}$, with a chromatogram area of 39914 at the retention time of 4.18 min with 296.50$297.50 \mathrm{~m} / \mathrm{z}$ and ESI-MS2 315.

Table-2: Analysis of progesterone from five samples from the benalu duku leaf crude extract.

\begin{tabular}{lcc}
\hline $\begin{array}{l}\text { Crude methanolic } \\
\text { extract of benalu duku } \\
\text { leaves }(\boldsymbol{\mu g} / \mathbf{m L})\end{array}$ & $\begin{array}{c}\text { Concentration } \\
\text { of progesterone } \\
(\boldsymbol{\mu g} / \mathbf{m L})\end{array}$ & $\begin{array}{c}\text { CRM } \\
(\boldsymbol{\mu g} / \mathbf{m L})\end{array}$ \\
\hline 50.000 & $28.268^{\mathrm{a}}$ & $29.010^{\mathrm{b}}$ \\
49.500 & $27.631^{\mathrm{a}}$ & $30.100^{\mathrm{b}}$ \\
48.900 & $29.441^{\mathrm{a}}$ & $28.090^{\mathrm{b}}$ \\
51.020 & $29.011^{\mathrm{a}}$ & $29.310^{\mathrm{b}}$ \\
50.020 & $28.222^{\mathrm{a}}$ & $29.380^{\mathrm{b}}$ \\
\hline
\end{tabular}

Superscripts a versus $b$ in the same row indicate similarity at $\mathrm{p}>0.05$ by the two-sample t-test.

methanol and $\mathrm{D}_{2} \mathrm{O}$ are presented in Figure-7, and those of the benalu duku leaf crude extract are presented in Figure-8. Table-2 shows the phyto progesterone in the matrix isolate from the benalu duku leaf crude extract after separation by an analytical column.

\section{Discussion}

The three peaks preceding those of the CRM (Figure-2) were predicted to be irrelevant and were identified as a noise peak, a turbulence effect from analyte entering the column, and another CRM component. The noise and turbulence peaks were easily identified. In practice, we can identify these peaks by triple or quadruple injection to test the stability of the peaks' RTs and chromatogram areas. Peaks that do not stabilize are irrelevant. However, the peak from another CRM compound was highly stable and was often observed at the same RT in the same chromatogram area. Bioactive determination in biological matrices such as meat will essentially obtain an irrelevant peak as described above including the determination of $\beta$-agonist drugs in goats[18-23]. Figure-2 shows that progesterone was eluted at approximately $6.107 \mathrm{~min}$, but the RT could easily drift by $2-4 \mathrm{~min}$ before and after $6.107 \mathrm{~min}$. A drift of 2-3 min before 6.107 min would be found if the analyte had been dissolved in the mobile phase solution $<30$ min prior. A drift of 2-3 min would occur after $6.107 \mathrm{~min}$ if the analyte was dissolved in the mobile phase solution for $>1 \mathrm{~h}$. A decrease in $\mathrm{pH}$ would indicate that the RT of analyte had been $>6.107 \mathrm{~min}$ after dissolved in the mobile phase for $>1 \mathrm{~h}$.

Phyto progesterone was eluted in the first group at the RT of 6.182 min (Figure-3). The RT of phyto progesterone apparently was more than RT of CRM at approximately drift of $0.075 \mathrm{~min}$. Shifting RT indicates that the phyto progesterone molecule undergoes physicochemical change during dissolution in mobile phase. The phyto progesterone peak at the $6.182 \mathrm{~min}$ RT was then pooled from HPLC samples for identification by FT-IR, LC-ESI-MS, and proton NMR. The other phyto progesterone peaks were impurity peaks from other compounds in the crude matrix extract of the benalu duku leaves (4.220, 4.728, 5.091, 5.641, 6.837, 7.187, $9.317,9.960,14.133,16.729$, and $18.914 \mathrm{~min}$ ). Other peaks from isolated compounds in the benalu duku leaf 


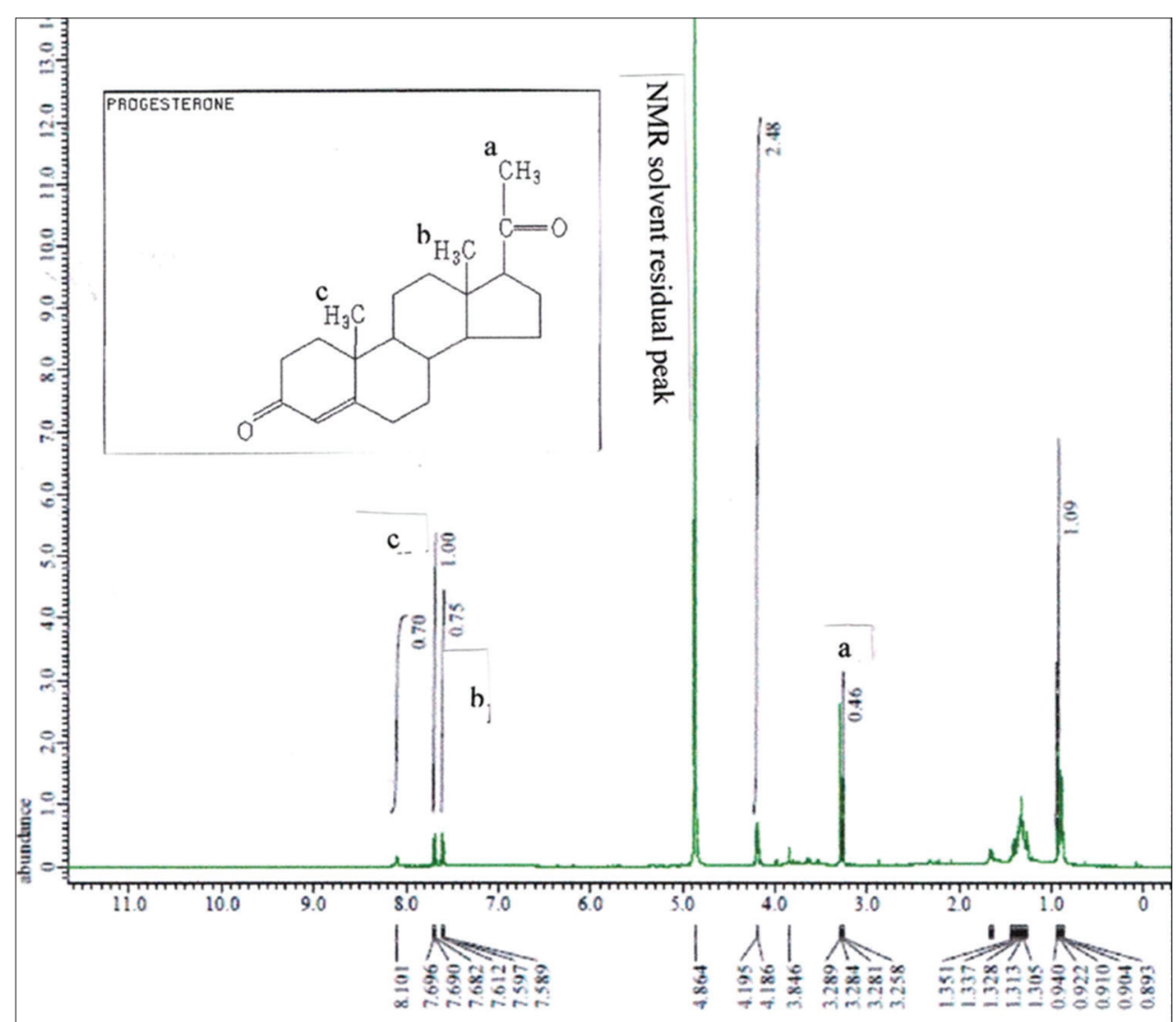

Figure-7: ${ }^{1} \mathrm{H}$-nuclear magnetic resonance spectrum of the progesterone certified reference material dissolved in methanol and $\mathrm{D}_{2} \mathrm{O}$ at a field strength of $9.389766 \mathrm{~T}$ and $400 \mathrm{MHz}$, analyzed by a JEOL RESONANCE instrument. Letters $a, b$, and $c$ indicate protons corresponding to carbon atoms 21,18 , and 19 of progesterone. The proton labeled "a" corresponds to an nuclear magnetic resonance solvent residual peak.

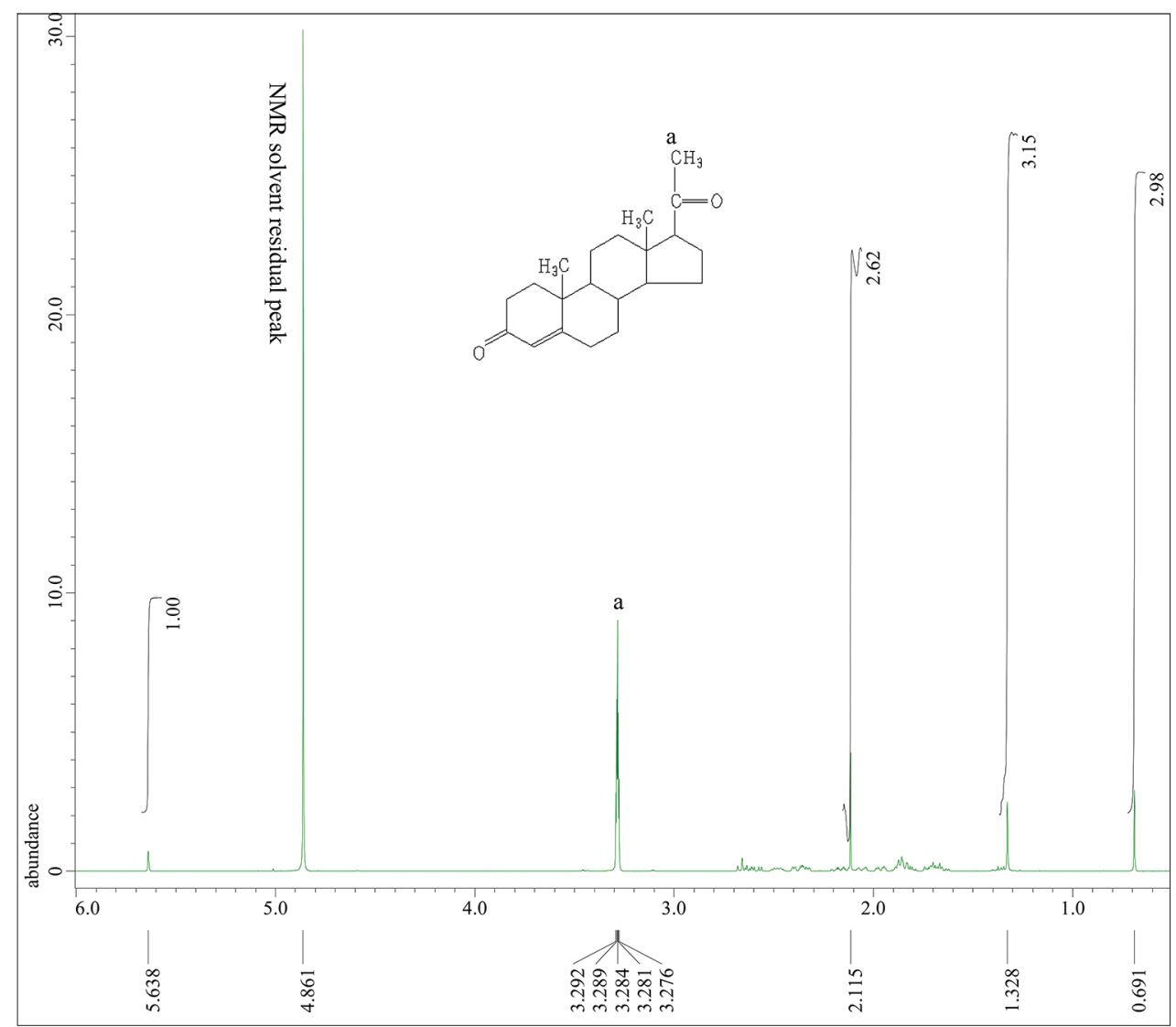

Figure-8: ${ }^{1} \mathrm{H}$-nuclear magnetic resonance spectrum of the crude extract isolated from benalu duku leaves dissolved in methanol and $\mathrm{D}_{2} \mathrm{O}$ at a field strength of $9.389766 \mathrm{~T}$ and $400 \mathrm{MHz}$, analyzed by a JEOL RESONANCE instrument. The $\delta$ of $5.638 \mathrm{ppm}$ was predicted to correspond to a proton in an aromatic ring. 
crude extract eluted at RTs from 7.300 to $12.672 \mathrm{~min}$ and 16.573 to $20.00 \mathrm{~min}$ were impurities peak and unrelated to compounds with progesterone-like effects, such as progesterone, medroxyprogesterone acetate, megestrol acetate, and dydrogesterone. The matrix compounds in this extract that eluted at RTs from 7.300 to $12.672 \mathrm{~min}$ and 16.573 to $20.00 \mathrm{~min}$ may be identified through more in-depth research.

Comparing the infrared CRM spectra with the benalu duku isolate (Table-1) was of interest because the overview shows that spectogram with the highest transmittance percent were found from $1300.00 \mathrm{~cm}^{-1}$ to $1700.00 \mathrm{~cm}^{-1}$. The predicted peak wavenumbers for the CRM at $1384.94 \mathrm{~cm}^{-1}$ and $1438.94 \mathrm{~cm}^{-1}$ were identical to those in the spectrum of the benalu duku isolate at $1317.43 \mathrm{~cm}^{-1}$ and $1386.86 \mathrm{~cm}^{-1}$, with high transmittance rates. The infrared spectrum indicated a single aromatic-ring with conjugated bonds. The infrared spectrum data described a single aromatic structure present at $1350.00 \mathrm{~cm}^{-1}-1450.00 \mathrm{~cm}^{-1}$. Another peak on the infrared spectrum at $1689.70 \mathrm{~cm}^{-1}-1699.34 \mathrm{~cm}^{-1}$ was identical between the CRM and the benalu duku isolate. These data indicated that wavenumbers $1680.00 \mathrm{~cm}^{-1}-1700.00 \mathrm{~cm}^{-1}$ were scissor vibrations from a naphthalene ring (Figure-1, rings $\mathrm{A}$ and $\mathrm{B}$ or rings $\mathrm{B}$ and $\mathrm{C}$ ). If this naphthalene ring was combined with the single aromatic ring (Figure-1, ring D), which was also indicated for the benalu duku isolate, the active substance was a molecule similar to phyto progesterone and the steroid, pregnane, derived at carbon bonds 1-21. Comparing the CRM's infrared peak at $2926.11 \mathrm{~cm}^{-1}$ to the benalu duku extract isolate's peak at $2941.54 \mathrm{~cm}^{-1}$ was unclear, although both peaks had high transmittance rates. However, the energies of the atoms in both peaks indicated involvement in the short bond structure of R-C-OH.

LC-ESI-MS is suitable for identifying unknown natural materials, especially by assessing their molecular weights. However, clarification is needed for testing using physicochemical-based instruments. The molecular mass of the active substance in the benalu duku extract isolate was identified as phyto progesterone (Table-2). The mean concentration of the benalu duku crude extract was $49.888 \mu \mathrm{g} / \mathrm{mL}$, with a mean concentration of $28.515 \mu \mathrm{g} / \mathrm{mL}$ of phyto progesterone. This result is approximately $97.728 \%$ of the pure CRM concentration (mean of $29.178 \mu \mathrm{g} / \mathrm{mL}$ ). Thus, ${ }^{\mathrm{H}} \mathrm{NMR}$ can be used to strengthen the LC-ESI-MS findings. Combining the two instruments produced mutually supportive interpretations [24-26]. Additional thermal analyses may be required to determine each substance's melting point.

Figure-7 apparently that proton labeled "a" was identified to carbon atoms 21 of CRM at right of chemical shift NMR solvent residual peak (ppm). The carbon atoms 18 and 19 of CRM were left of chemical shift NMR solvent residual peak as labeled of "b" and "c" (ppm). Comparing to Figure-8 predicted that the proton NMR of the product isolated by the Lazuardi method might have contained protons from compounds other than progesterone [11,27-34]. The proton labeled "a" was a specific peak of carbon atom no 21 of progesterone molecule referred to Figure-1. However, at the right of chemical shift, NMR solvent residual peak in $2.115 \mathrm{ppm}, 1.328 \mathrm{ppm}$, and $0.691 \mathrm{ppm}$ was not specific protons from impurities compounds. Other impurities compound at $\delta$ of $5.638 \mathrm{ppm}$ was predicted to correspond to a proton in an aromatic ring of impurities peak.

The LC-ESI-MS analysis indicated that part of the isolation process in running the HPLC from minutes 4 to 20 occurred as follows. From minutes 4 to 6.5 , the eluted solution may have contained progesterone compounds; however, that isolate did not contain medroxyprogesterone acetate, megestrol acetate, or dydrogesterone. Table- 2 shows that samples $\mathrm{n}=1-\mathrm{n}=5$ contained progesterone at approximately $28.515 \pm 0.713 \mu \mathrm{g} / \mathrm{mL}$, as described below $(\mathrm{p}=0.189)$. The progesterone CRM described in Table-2 was apparently of a stable concentration, ranging from $28.08 \mu \mathrm{g} / \mathrm{mL}$ to $30.1 \mu \mathrm{g} / \mathrm{mL}$ [29-36].

\section{Conclusion}

The phyto progesterone compound was found in the separation process between 4 and 6.5 min during the HPLC with an analytical column. The specific RT was detected at $6.107 \mathrm{~min}$. Other compounds with progesterone-like effects were not found in the products separated from the benalu duku leaves. Future recommendations include exploring methanolic extract from benalu duku leaves to obtain other compounds with progesterone-like effects. The methanolic crude extract of benalu duku leaves with a mean concentration of $49.888 \mu \mathrm{g} /$ $\mathrm{mL}$ after the adsorption-partition separation process contained $28.515 \pm 0.713 \mu \mathrm{g} / \mathrm{mL}$ of progesterone.

\section{Authors' Contributions}

LM collected plant material, performed the experiment, analyzed the data, and wrote the manuscript. $\mathrm{BH}$ and $\mathrm{EPH}$ participated in analyzing animal experiments after treatment. All authors read and approved the final manuscript.

\section{Acknowledgments}

The research team appreciates the Dean, Faculty of the Veterinary Medicine, Universitas Airlangga, Indonesia, for providing logistical support and the President of the Institute of Tropical Medicine, Universitas Airlangga for support in the laboratory analytics. Funding for his project came from the Indonesian Government by the Ministry of Research and Technology and Higher Education, which supported financing through 2017, contract number 004/ADD/SP2H/LT/DRPM/2017, in addition to the authors' resources.

\section{Competing Interests}

The authors declare that they have no competing interests. 


\section{Publisher's Note}

Veterinary World remains neutral with regard to jurisdictional claims in published institutional affiliation.

\section{References}

1. Patel, S. and Panda, S. (2014) Emerging roles of mistletoes in malignancy management. 3 Biotech, 4(1): 13-20.

2. Agustina, T.E. and Sofy, P. (2017) Extract from mango mistletoes Dendrophthoe pentandra ameliorates TNBSinduced colitis by regulating $\mathrm{CD} 4+\mathrm{T}$ cells in mesenteric lymph nodes. BMC Complement. Altern. Med., 17(1): 468-476.

3. Elkin, Y.N., Kulesh, N.I., Stepanova, A.Y., Solovieva, A.I., Kargin, V.M. and Manyakhin, A.Y. (2018) Methylated flavones of the hairy root culture Scutellaria baicalensis. J. Plant Physiol., 11(231): 277-280.

4. Bambang, H. and Lazuardi, M. (2013) Assessment of luteinizing testosterone prolactin estrogen hormone after giving crude methanol extract of benalu duku leaves on healthy adult female rat. Proc. Natl. Indones. Vet. Pharm. Pharmacol. Assoc., 2(1): 29-31.

5. Endharti, A.T., Wulandari, A., Listyana, A., Norahmawati, E. and Permana, S. (2016). Dendrophthoe pentandra (L.) Miq extract effectively inhibits inflammation, proliferation and induces p53 expression on colitis-associated colon cancer. BMC Complement. Altern. Med., 16(1): 374-382.

6. Zamani, A., Mat, J.S.A., Al-Jamal, H.A., Sul'ain, M.D. and Johan, M.F. (2016) Anti-proliferative effects of Dendrophthoe pentandra methanol extract on BCR/ABLpositive and imatinib-resistant leukemia cell lines. Asian Pac. J. Cancer Prev., 17(11): 4857-4861.

7. Elsyana, V., Bintang, M. and Priosoeryanto, B.P (2016) Cytotoxicity and antiproliferative activity assay of clove mistletoe (Dendrophthoe pentandra (L.) Miq.) leaves extracts. Adv. Pharmacol. Sci., 2016(1): 1-6.

8. Lazuardi, M. and Bambang, H. (2014) Dendrophthoe pentandra methanolic leaf extract increases progesterone levels in female rats. Univ. Med., 33(2): 100-108.

9. Lazuardi, M. and Bambang, H. (2016) LC ESI-MS and FT-IR analysis of Dendrophthoe pentandra L. Miq leaf methanolic extracts to identify compounds with progesterone-like effects. Pak. J. Nutr., 15(3): 274-282.

10. O'Neill, A.R. and Rana, S.K. (2016) An ethnobotanical analysis of parasitic plants (Parijibi) in the Nepal Himalaya. J. Ethnobiol. Ethnomed., 12(14): 1-15.

11. Lazuardi, M. and Bambang, H. (2017) Technique separation phyto-hormones of progesterone on crude extract benalu duku leaf by analytical column of high performance liquid chromatography. Proc. Natl. Indones. Vet. Pharm. Pharmacol. Assoc., 3(1):45-48.

12. Maruška, A., Ragažinskienė, O., Vyšniauskas, O., Kaškoniene, V., Bartkuvienė, V., Kornyšova, O., Briedis, V. and Ramanauskienè, K. (2014) Flavonoids of willow herb (Chamerion angustifolium (L.) Holub) and their radical scavenging activity during vegetation. Adv. Med. Sci., 59(1): 136-141.

13. Abe, K., Matsuura, H., Ukai, M., Shimura, H., Koshino, H and Suzuki, T. (2017) $\mathrm{N}^{1}, \mathrm{~N}^{14}$-diferuloylspermine as an antioxidative phytochemical contained in leaves of Cardamine fauriei. Biosci. Biotechnol. Biochem., 81(10): 1855-1860.

14. Lee, S.E., Lim, C., Ahn, S.C. and Cho, S. (2017) A study of the anti-cancer effects of the hexane fraction of the methanol extract of Forsythiae fructus. Pharmacogn. Mag., 13(52): 719-724.

15. Maraghehpour, B., Khayamzadeh, M., Najafi, S. and Kharazifard, M. (2016) Traditionally used herbal medicines with antibacterial effect on Aggegatibacter actinomycetemcomitans: Boswellia serrata and Nigella sativa. J. Indian Soc. Periodontol., 20(6): 603-607.
16. Morrill, B.A., Madden, G.J., Wengreen, H.J., Fargo, J.D. and Aguilar, S.S. (2016) A randomized controlled trial of the food dudes program: Tangible rewards are more effective than social rewards for increasing short and long-term fruit and vegetable consumption. J. Acad. Nutr. Diet., 116(9): 618-629.

17. Pietrzak, W., Nowak, R., Gawlik-Dziki,U., Lemieszek, M.K. and Rzeski, W. (2017) LC-ESI-MS/MS identification of biologically active phenolic compounds in mistletoe berry extracts from different host trees. Molecules, 22(4): 624-639.

18. Lazuardi, M., Bambang, H. and Restiadi, T.I. (2018) Calculated of withdrawal times of clenbuterol in goats to obtain safe time of slaughter. Vet. World, 11(6): 731-738.

19. Lazuardi, M. (2016) Bagian Umum Ilmu Farmasi Veteriner. $1^{\text {st }}$ ed. Ghalia Indonesia Press, Jakarta.

20. Kuang, Y., He, B., Du, Y., Li, J., Wang, D., Bi, K. and Li, Q. (2016) Simultaneous determinations of eleven bioactive components in suanzaoren decoction granules by high-performance liquid chromatography and its application to the quality control in production processes. Anal. Sci., 32(9): 931-936.

21. Seo, U.M., Zhao, B.T., Kim, Y.H., Kang, J.S., Son, J.K. and Woo, M.H. (2016) Simultaneous analysis of seven marker compounds from Saposhnikoviae radix, Glehniae radix and Peucedani japonici radix by HPLC/PDA. Arch. Pharm. Res., 39(5): 695-704.

22. Seo, C.S. and Shin, H.K. (2017) Simultaneous quantification of eight marker compounds in yongdamsagan-tang using high-performance liquid chromatography equipped with photodiode array detector. J. Chromatogr. Sci., 55(9): 926-933.

23. Hemanth, K.A.K., Polisetty, A.K., Sudha, V., Vijayakumar, A. and Ramachandran, G. (2018) A selective and sensitive high performance liquid chromatography assay for the determination of cycloserine in human plasma. Indian J. Tuberc., 65(2): 118-123.

24. Wang, J., Zheng, S., Xu, Y., Hu, H., Shen, M. and Tang, L. (2018) Development of a novel HPLC method for the determination of the impurities in desonide cream and characterization of its impurities by 2D LC-IT-TOF MS. J. Pharm. Biomed. Anal., 161: 399-406.

25. Yasir, M., Sultana, B., Nigam, P.S. and Owusu-Apenten, R. (2016) Antioxidant and geno protective activity of selected Cucurbitaceae seed extracts and LC-ESIMS/MS identification of phenolic components. Food. Chem., 199: 307-313.

26. Çiçek, S.S., Girreser, U. and Zidorn, C. (2018) Quantification of the total amount of black cohosh cycloartanoids by integration of one specific ${ }^{1} \mathrm{H}$ NMR signal. J. Pharm. Biomed. Anal., 155: 109-115.

27. Mahrous, E.A. and Mohamed A.F. (2015) Two dimensional NMR spectroscopic approaches for exploring plant metabolome: A review. J. Adv. Res., 6(1): 3-15.

28. Rocha, R.S., Kassuya, C.A., Formagio, A.S., Mauro, M.O., Andrade-Silva, M., Monreal, A.C., Cunha-Laura, A.L., Vieira, M.C. and Oliveira, R.J. (2016) Analysis of the anti-inflammatory and chemopreventive potential and description of the antimutagenic mode of action of the Annona crassiflora methanolic extract. Pharm. Biol., 54(1): 35-47.

29. Augustijn, D., Roy, U., van Schadewijk, R., De Groot, H.J.M. and Alia, A. (2016) Metabolic profiling of intact Arabidopsis thaliana leaves during circadian cycle using $1 \mathrm{~h}$ high resolution magic angle spinning NMR. PLoS One, 11(9): 1-17.

30. Amalina, A.A., Raghunath, P., Intan S.I., Amin, I, Alfi, K., Faridah, A. and Khozirah, S. (2017) Urinary metabolomics study on the protective role of Orthosiphon stamineus in streptozotocin induced diabetes mellitus in rats via ${ }^{1} \mathrm{H}$ NMR spectroscopy. BMC Complement. Altern. Med., 17(1): 278-281.

31. Baira, S.M., Sigalapalli, D.K., Bathini, N.B., Srinivas, R., Talluri, M.V.N. (2018) LC/QTOF/MS/MS characterization, molecular docking and in silico toxicity prediction studies 
on degradation products of anagliptin. J. Pharm. Biomed. Anal., 159: 92-99.

32. Schindler, A.E., Campagnol, C., Druckmann, R., Huber, J., Pasqualini, J.R., Schweppe, K.W. and Thijssen, J.H. (2003) Classification and pharmacology of progestins. Maturitas, 46(1): S7-S16.

33. Van Dusschoten, D., Metzner, R., Kochs, J., Postma, A.J., Pflugfelder, D., Bühler, J., Schurr, U. and Jahnke, S. (2016) Quantitative 3D analysis of plant roots growing in soil using magnetic resonance imaging. Plant Physiol., 170(3): 1176-1188.

34. Al-Zuaidy, M.H., Mumtaz, M.W., Hamid, A.A. and Ismail, A. (2017) Biochemical characterization and ${ }^{1} \mathrm{HNMR}$ based metabolomics revealed Melicope lunu-ankenda leaf extract a potent anti-diabetic agent in rats. $B M C$ Complement. Altern. Med., 17(1): 359-376.

35. Mohamed, S., Razis, A.F.A., Watanabe, S., Kuzhiumparambil, U. and Fu, S. (2018) In vitro metabolism of synthetic cannabinoid AM1220 by human liver microsomes and Cunninghamella elegans using liquid chromatography coupled with high resolution mass spectrometry. Forensic Toxicol., 36(2): 435-446.

36. Hernández-Bolio, G.I., Kutzner, E., Eisenreich, W., de Jesús Torres-Acosta, J.F. and Peña-Rodríguez, L.M. (2018) The use of ${ }^{1}$ H-NMR metabolomics to optimize the extraction and preliminary identification of anthelmintic products from the leaves of Lysiloma latisiliquum. Phytochem. Anal., 29(4): 413-420.

$* * * * * * * *$ 